\title{
Management of perforation after endoscopic retrograde cholangiopancreatography
}

\author{
Cengiz Tavusbay, M.D., ${ }^{1}$ Emrah Alper, M.D., ${ }^{2}$ Melek Gökova, M.D.,, ${ }^{1}$ Erdinç Kamer, M.D., ${ }^{1}$ \\ Haldun Kar, M.D., ${ }^{1}$ Kemal Atahan, M.D., ${ }^{1}$ Oğuzhan Özşay, M.D., ${ }^{1}$ Özlem Gür, M.D., ${ }^{1}$ \\ Necat Cin, M.D., ${ }^{1}$ Emir Çapkınoğlu, M.D., ${ }^{1}$ Evren Durak, M.D. ${ }^{1}$
}

${ }^{1}$ Department of General Surgery, İzmir Katip Çelebi University Atatürk Training and Researh Hospital, İzmir-Turkey ${ }^{2}$ Department of Gastroenterology, İzmir Katip Çelebi University Atatürk Training and Researh Hospital, İzmir-Turkey

\begin{abstract}
BACKGROUND: Endoscopic retrograde cholangiopancreatography (ERCP)-related perforation is an infrequent complication. It is associated with significant morbidity and mortality. The present study is an evaluation of experience with management and outcomes of ERCP-related perforations and a review of relevant literature.
\end{abstract}

METHODS: Between January 2008 and January 20I5, a total of 9383 ERCPs were performed in endoscopy unit. A total of 29 perforations $(0.33 \%)$ were identified and retrospectively reviewed.

RESULTS: Of the 29 patients, 18 were female and II patients were male, with mean age of 70.5 years (range 33-99 years). According to Stapfer's classification, the 29 patients with ERCP related perforations included 5 type I perforations, 14 type 2 perforations, 7 type 3 perforations, and 3 cases of type 4 perforation. In total, 15 of 29 patients with ERCP perforation were operated on. Nine (60\%) of those who underwent surgery were discharged uneventful, but $6(40 \%)$ patients died due to postoperative complications and/or associated comorbidities. Seven (24.1\%) of 29 patients had undergone endoscopic treatment and 5 of the 7 were discharged from the hospital without any problems; however, peritonitis occurred in 2 patients whose initial endoscopic treatment failed. The first of these 2 patients underwent surgery and was discharged uneventfully, but second patient, who refused surgery, died due to sepsis. Six patients were successfully treated with conservative management. Surgery could not be performed in the remaining 2 patients, who died of sepsis following peritonitis; I refused surgery, the other had sudden cardiopulmonary arrest during induction of general anesthesia. Mean hospital stay was 13.2 days (range: $2-57$ days). In all, 9 (31\%) patients died during period of the study.

CONCLUSION: ERCP-related perforation is uncommon complication, but an extremely serious condition. Early diagnosis and prompt management are most important to reduce associated significant morbidity and mortality rates. The most appropriate treatment course should be determined on case-by-case basis.

Keywords: Endoscopic retrograde cholangiopancreatography; endoscopic treatment; perforation.

\section{INTRODUCTION}

Currently, endoscopic retrograde cholangiopancreatography (ERCP) is widely used for both diagnostic and therapeutic purposes in pancreaticobiliary disorders. ERCP is broadly re-

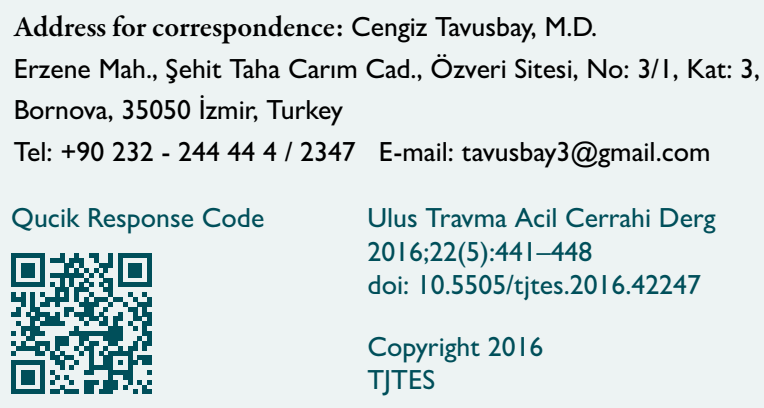

garded as a safe procedure; however, ERCP-related complications, such as perforation, bleeding, and pancreatitis can occur, even when procedure is performed by an experienced physician. Since ERCP-related perforation is rare but serious complication accompanied by risk of morbidity and mortality, early diagnosis and treatment are extremely important. ${ }^{[1-3]}$ Accurate diagnosis and effective management of perforation depends on early recognition of clinical features and accurate interpretation of diagnostic imaging.

Although some ERCP-related perforations can be successfully managed without surgery, there is currently no clear consensus on optimal treatment modality that can be used in all cases. Several authors have defined different classification schemes for retroperitoneal perforations of ERCP and have suggested a selective management strategy based on type of 
injury. ${ }^{[4-6]}$ Additionally, outcome is determined by several factors, including comorbidities, clinical status of patient, size and location of perforation, radiographic imaging findings, and interval between perforation and initiation of therapy.

The present study is an assessment of experience with ERCPrelated perforations at a university hospital.

\section{MATERIALS AND METHODS}

A total of 9383 ERCPs were performed in the endoscopy unit of İzmir Katip Çelebi University Atatürk Training and Research Hospital between January 2008 and January 2015. Of these, a total of 29 had related perforation $(0.3 \%)$, all of which were identified using hospital medical records system. Patient demographics, including age, sex, American Society of Anesthesiologists (ASA) score, and comorbidities (e.g., chronic renal failure [CRF], diabetes mellitus [DM], coronary heart disease [CHD] and malignancy) were assessed. For each of the 29 perforations, indications for ERCP, findings at ERCP, time interval between perforation and surgery, clinical presentation, radiographic findings, management, and outcomes were analyzed. In addition, postoperative data, including complications, length of stay (LOS), secondary interventions, and readmissions within 30 days after discharge were evaluated.

In endoscopy unit, almost all of the ERCP procedures were performed for therapeutic reasons; all of the patients had primary biliary disease, which was diagnosed with other diagnostic methods, including abdominal computed tomography (CT), magnetic resonance cholangiopancreatography (MRCP), abdominal ultrasonography (AUS) or endoluminal ultrasonography (EUS). ERCP indications were established after considering clinical symptoms, history, laboratory results, and radiological imaging results. Endoscopic sphincterotomy was performed in 8123 patients (86.5\%) and 1260 patients (13.5\%) underwent a pre-cut papillotomy. Standard sphincterotomy was performed by an experienced endoscopist with extensive experience in therapeutic ERCP. Pre-cutting techniques were used only in cases with unsuccessful cannulation.

ERCP was performed using therapeutic duodenoscope (TJF 180; Olympus Corp., Tokyo, Japan) by an experienced team using standard technique. In most cases, standard biliary sphincterotomy was used for biliary cannulation. Ionic contrast media diatrizoate (Urografin 76\%; Schering AG, Berlin, Germany) was used to view bile and pancreatic duct. Primary team conducted postinterventional observation of all patients for first 24 hours to determine any possible procedurerelated complications. Routine laboratory tests, including complete blood count (CBC), serum amylase, and C-reactive protein (CRP), were performed the first day following ERCP. If there were no complications, patients were discharged within 24 hours post-procedure.
In the present study, ERCP indications included choledocholithiasis $(n=21$, with cholangitis in 4 patients and acute pancreatitis in I patient), obstructive jaundice with pancreatic mass $(n=3)$, external biliary fistula after surgery for hydatid disease ( $n=2$, I patient with cholangitis), papilla Vateri tumor $(n=2$, I patient with cholangitis), and dilated common bile duct (CBD) caused by external compression of metastatic mass $(n=l)$.

Several different classifications for ERCP-perforations have been reported in the literature. ${ }^{[4,5]}$ In the current study, Stapfer's classification system was used, which consists of the following types: I) Lateral or medial duodenal wall perforation, 2) perivaterian injury, 3) distal bile duct injury related to wire/ basket instrumentation, and 4) retroperitoneal air alone. ${ }^{[4]}$

All cases were followed by an attendant gastroenterologist, who consulted a surgeon, interventional radiologist, or anesthesiologist, if needed. Immediate emergency surgery is often required if signs and symptoms of peritonitis develop within the first 72 hours. Other conservative medical treatments include withholding of oral intake, hydration, proton pump inhibitory (PPI) therapy, somatostatin (SS), intravenous antibiotics, and serial abdominal examinations with radiological studies.

The present study was approved by the ethics committee of İzmir Katip Çelebi University, Atatürk Training and Research Hospital.

Descriptive statistics were used to evaluate demographic and clinical characteristics of patients and treatments; correlation analyses were not feasible due to limited number of patients and because many values were unavailable.

\section{RESULTS}

Demographic and clinical features of patients with ERCPrelated perforation are summarized in Table I. A total of 29 ERCP-related perforations were identified in this study. Mean age of patients was 70.5 years (range: 33-99 years), and there were 18 female and II male patients. It is remarkable to note that 18 patients $(62 \%)$ were older than 70 years of age at the time of ERCP-related perforation diagnosis. In all, there were 5 type I perforations, 14 type 2 perforations, 7 type 3 perforations, and 3 type 4 perforations.

As can be easily understood from Table I, a significant proportion of patients had I or more comorbidity. Patients had mean ASA score of 2.28 (range: 1-3). Signs and symptoms of peritonitis developed in 18 patients; mild abdominal pain or discomfort occurred in II patients. Abdominal radiography or CT indicated that $15(51.7 \%)$ patients had both free intraperitoneal air and retroperitoneal air, and 14 (48.3\%) had only retroperitoneal air (Fig. Ia, b). Five of the 29 patients had 
Table I. Demographic, clinical, and laboratory features of patients with ERCP-related perforation

\begin{tabular}{|c|c|c|c|c|c|}
\hline Parameter & Type I $(n=5)$ & Type $2(n=14)$ & Type $3(n=7)$ & Type $4(n=3)$ & Total \\
\hline Age (years) & 58-99 (80.2) & $37-94(69.6)$ & $52-88(77)$ & $33-51(43.6)$ & $33-99(70.5)$ \\
\hline$>70$ years & 4 & 8 & 6 & - & $18(62 \%)$ \\
\hline Gender (male/female) & $2 / 3$ & $4 / 10$ & $4 / 3$ & $1 / 2$ & $11 / 18$ \\
\hline ASA score (mean) & 3 & 2.29 & 2.1 & 1.3 & 2.28 \\
\hline \multicolumn{6}{|l|}{ Comorbidities } \\
\hline Diabetes mellitus & 1 & 3 & & & 4 \\
\hline CAD/and/or hypertension & 3 & 9 & 4 & & 16 \\
\hline Hashimato's thyroiditis & & & & 1 & 1 \\
\hline Parkinson's disease & & 1 & & & 1 \\
\hline Alzheimer's disease & & 1 & & & 1 \\
\hline Rheumatoid arthritis+steroid use & & 1 & & & 1 \\
\hline COPD & & 1 & & & 1 \\
\hline Chronic renal failure & & 1 & & & 1 \\
\hline HBP malignancy & 2 & 2 & 2 & & 6 \\
\hline Hepatic hydatid disease & & & 1 & 1 & 2 \\
\hline \multicolumn{6}{|l|}{ Clinical presentation } \\
\hline Peritonitis & 5 & 10 & 3 & & 18 \\
\hline Abdominal pain or discomfort & - & 4 & 4 & 3 & II \\
\hline Fever & 2 & 6 & 1 & - & 15 \\
\hline \multicolumn{6}{|l|}{ Emphysema (subcutaneous and/or } \\
\hline mediastinal emphysema) & 2 & 2 & 1 & - & 5 \\
\hline \multicolumn{6}{|l|}{ Laboratory findings } \\
\hline Elevated C-reactive protein & 5 & 12 & 6 & 3 & 26 \\
\hline Leukocytosis & 5 & 11 & 5 & 3 & 24 \\
\hline Elevated amylase & 3 & 8 & 5 & I & 17 \\
\hline
\end{tabular}

ERCP: Endoscopic retrograde cholangiopancreatography; ASA: American Society of Anesthesiologists; COPD: Chronic obstructive pulmonary disease; HBP: Hepatobiliary and pancreatic.

subcutaneous or mediastinal emphysema. While 18 of the 29 patients had obvious signs and symptoms of peritonitis, the other 6 patients had no symptoms of peritonitis, but they had both moderate upper abdominal pain and free intraperitoneal air (I patient) or pneumoretroperitoneum ( 5 patients). Five patients who were endoscopically treated for ERCP perforation only had mild abdominal pain, which persisted for I to 2 days.
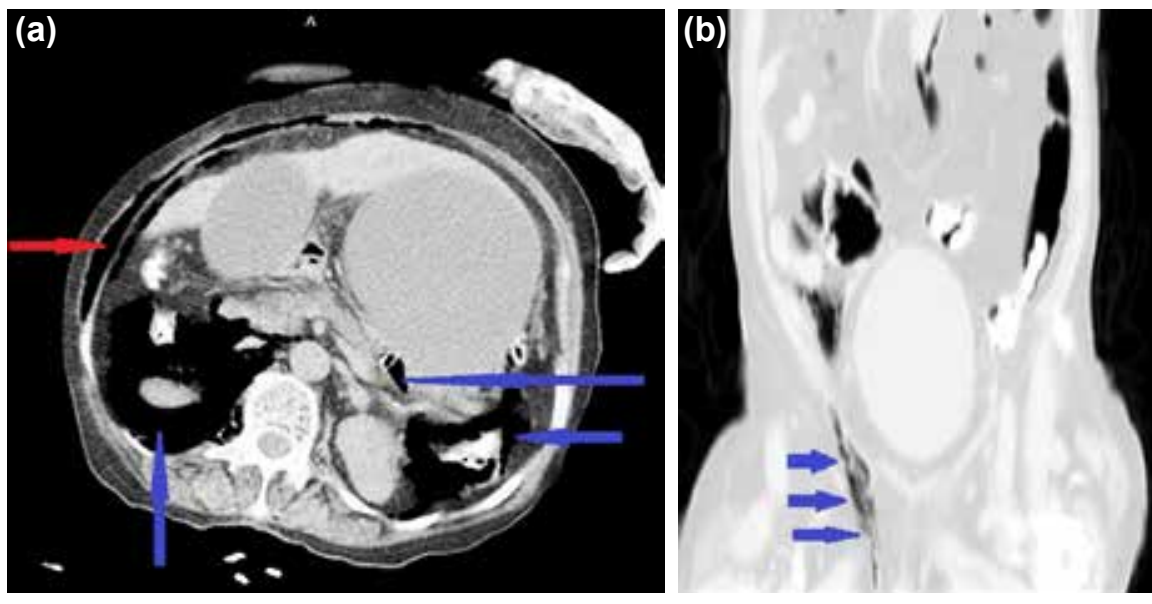

Figure 1. (a) Abdominal CT following perforation shows pneumoperitoneum, pneumoretroperitoneum (blue arrows), and subcutaneous emphysema (red arrow). (b) Coronal abdominal CT scan also shows subcutaneous emphysema in the right inguinal region (blue arrow). 
C-reactive protein (CRP) levels were elevated in 26 patients (I.17-37.2 mg/L), 24 patients had leukocytosis (II600$36400 / \mathrm{mm}^{3}$ ), and amylase values were elevated in 17 patients (250-3169 IU/L).

As illustrated in Table 2, ERCP indications of patients were as follows: choledocholithiasis ( $n=21,4$ with acute cholangitis, I acute pancreatitis), cancer $(n=6)$, and biliary fistula following surgery for hepatic hydatid disease $(n=2)$. Cancers found were: pancreas head $(n=2)$, papilla Vateri tumor $(n=2$, I with acute cholangitis), Klatskin tumor $(n=1)$, extrabiliary tumor compressing biliary system $(n=1)$. Of the 29 patients with ERCP-related perforations, 12 perforations resulted from papillotomy, 12 resulted from inserting a balloon or basket into CBD after papillotomy while stone was being removed, and 5 resulted from lateral duodenal wall perforation due to trauma of duodenoscope. Unexpected technical difficulties were encountered in 12 patients. Of these, 5 patients had duodenal diverticula, 2 had increased fragility due to malignant tumor, 2 had subsequent ERCP ( 3 times in I week), I had bile duct stenosis due to tumor, I had metastatic hepatoduodenal lymphadenopathy, and I patient with Billroth II gastrectomy had duodenal wall perforation. Standard sphincterotomy was performed in 23 patients with ERCP perforation, while pre-cut sphincterotomy was performed in 5 patients. Perforation was detected or suspected in II (37.9\%) of the 29 patients during ERCP. Six (20.7\%) of the 29 cases were diagnosed with perforation within 24 hours of ERCP (mean: I I.3 hours, range: 6-22 hours). The other $12(41.4 \%)$ patients were diagnosed with perforation more than 24 hours after ERCP (mean: 54.4 hours, range: 26-144 hours).

As can be seen in Table 3, 15 (5I.7\%) of the 29 patients underwent surgery due to peritonitis following ERCP procedure. Eleven patients underwent exploratory laparotomy and drainage of retroperitoneal and intraperitoneal spaces. Five of these II patients had additional surgical procedure (choledocotomy and T-tube drainage in 3 patients, cholecystectomy in 2 patients, and choledocoenterostomy in I pa-

Table 2. Data related to indications of ERCP, technical difficulties, type of endoscopic sphincterotomy, and time of diagnosis of perforation

\begin{tabular}{|c|c|c|c|c|c|c|}
\hline \multirow{2}{*}{\multicolumn{2}{|c|}{ ERCP data }} & \multicolumn{5}{|c|}{ Perforation Type } \\
\hline & & Type I $(n=5)$ & Type $2(n=14)$ & Type $3(n=7)$ & Type $4(n=3)$ & Total \\
\hline \multirow[t]{3}{*}{ I) } & ERCP indications & & & & & \\
\hline & Common bile duct stone & $\begin{array}{c}3 \text { (with I } \\
\text { cholangitis) }\end{array}$ & $\begin{array}{l}\text { I2 (with I } \\
\text { cholangitis) }\end{array}$ & $\begin{array}{l}4 \text { (with I acute } \\
\text { pancreatitis } 2 \text { ) }\end{array}$ & $\begin{array}{c}\text { (with } 2 \\
\text { cholangitis) }\end{array}$ & $\begin{array}{c}\text { 2I (with } 4 \text { cholangitis, } \\
\text { I acute } \\
\text { pancreatitis) }\end{array}$ \\
\hline & $\begin{array}{l}\text { Cancer (pancreatic, duodenal } \\
\text { or extrabiliary tumor) }\end{array}$ & $\begin{array}{c}2 \text { (with I } \\
\text { cholangitis) }\end{array}$ & 2 & $\begin{array}{c}2 \text { (with I } \\
\text { cholangitis) }\end{array}$ & & 6 ( 2 cholangitis) \\
\hline
\end{tabular}

Biliary fistula following surgery

for hepatic hydatid disease

2) Technical difficulties $(n=12)$

Ampullary duodenal diverticulum

Increased mucosal fragility of papilla

Bile duct stenosis due to tumor

and metastatic lymphadenopathy

Billroth II operation

Subsequent ERCP (3 times in a week)

3) Type of ES

Standard

Precut

4

$-$

4) Diagnosis time

During ERCP

Early presentation ( $<24$ hours)

Late presentation ( $>24$ hours) cholangitis)

ERCP: Endoscopic retrograde cholangiopancreatography; ES: Endoscopic sphincterotomy 
Table 3. Data regarding method of management of post-ERCP perforation, hospital stay, and mortality

\begin{tabular}{|c|c|c|c|c|c|}
\hline \multirow[t]{2}{*}{ Parameter } & \multicolumn{5}{|c|}{ Perforation type } \\
\hline & Type I $(n=5)$ & Type $2(n=14)$ & Type $3(n=7)$ & Type $4(n=3)$ & Total \\
\hline \multicolumn{6}{|l|}{ I. Treatment modality } \\
\hline A. Surgery & 4 & 9 & 2 & & 15 \\
\hline I) Primary repair & 2 & & & & 2 \\
\hline 2) Whipple procedure & I & & & & I \\
\hline \multicolumn{6}{|l|}{ 3) Cholesystectomy, tube } \\
\hline \multicolumn{6}{|l|}{ duodenostomy, pyloric } \\
\hline \multicolumn{6}{|l|}{ exclusion, gastrojejunostomy, } \\
\hline Braun anastomosis) & I & & & & 1 \\
\hline Surgical drainage of & & 9 (with Cholecystectomy & 2 (with T-tube & & \\
\hline retroperitoneal and & & in 2, T-tube drainage after & drainage after & & \\
\hline \multirow[t]{2}{*}{ peritoneal spaces } & & choledocotomy in 2 & choledocotomy & & \\
\hline & & choledocoenterostomy in I) & in I) & & II \\
\hline B. No surgery for reasons & 1 & 1 & 1 & & 3 \\
\hline $\begin{array}{l}\text { C. Conservative medical } \\
\text { treatment }\end{array}$ & - & 1 & 2 & 3 & 6 \\
\hline D. Endoscopic treatment & $\begin{array}{l}\text { I (Unsuccessful } \\
\text { clipping) }\end{array}$ & $\begin{array}{l}4 \text { (3 successful, I patient } \\
\text { underwent surgery) }\end{array}$ & 2 & $\begin{array}{c}7 \\
\text { (2 unsuccessful) }\end{array}$ & \\
\hline II. Mean hospital stay (days) & $15.6(6-23)$ & $14.6(2-57)$ & $12(3-40)$ & $6.6(2-16)$ & $13.2(2-57)$ \\
\hline III. Death & $3(60 \%)$ & $5(35.7 \%)$ & $2(28.5 \%)$ & - & $10(34.4 \%)$ \\
\hline
\end{tabular}

ERCP: Endoscopic retrograde cholangiopancreatography.

tient). Importantly, in II of the 15 patients who underwent surgery, perforation site could not be found due to severe inflammation and edema. Two patients underwent primary repair of duodenum. One of these (58 years old) had history of Billroth II operation and type 2 DM. He also had choledocholithiasis with acute cholangitis. Even though diagnosis was made early and surgery was performed immediately, patient died due to uncontrolled severe complications related to anesthesia. The second patient with choledocholithiasis was 99 years old, and also had ampullary duodenal diverticulum. She was still alive at the age of 101 at the time of this report, and did not have any problems related to the surgery. The third patient underwent Whipple procedure because she could not undergo primary repair and because she had malignant tumor of the papilla of Vater. Postoperative course was uneventful, and she was discharged from the hospital in good health. Another patient with choledocholithiasis underwent cholecystectomy, tube duodenostomy, pyloric exclusion, gastrojejunostomy, and Braun anastomosis for peritonitis following ERCP-related perforation; this patient died due to septic complications. The fifth patient in this group had acute abdomen; this patient died due to sepsis 6 days after ERCP despite endoscopic treatment during ERCP procedure (endoscopic clipping). She was admitted to clinic with jaundice, and was given preliminary diagnosis of pancreatic cancer. Although revision operation was offered, she and her family refused the surgery due to her advanced age and multiple comorbidities.

In total, 7 patients (24.1\%) were endoscopically treated by gastroenterologist (e.g., metal stent placement and/or clipping). Five of these 7 patients were managed conservatively because they had no symptoms of peritonitis and they were discharged without any problems. Peritonitis occurred in 2 patients whose initial endoscopic treatment failed. The first of these patients underwent surgery and was discharged uneventfully, but second patient, who refused surgery, died due to sepsis in first week after ERCP.

After perforation diagnosis, 6 of the 29 patients were immediately treated with conservative management for 2-16 days because signs and symptoms of manifest peritonitis did not develop. All of these 6 patients successfully recovered, and were discharged uneventful.

Overall, mean hospital stay was 13.2 days (range: 2-57 days), and a total of 10 (34.4\%) patients died in this study. Seven (46.6\%) of the 15 patients who underwent surgery died due to septic and/or other complications during early postoperative period. 


\section{DISCUSSION}

ERCP-related perforation is rare but serious complication. Incidence of perforation has been reported to range between $0.01 \%$ and $2.1 \%{ }^{[1-3]}$ In the current series, rate of ERCP-related perforation was $0.3 \%$, which is similar to the literature for age range of 33 to 99 years. Most authors have reported that major risk factors for ERCP-related perforations include sphincter of Oddi dysfunction (SOD), Billroth II anatomy, intramural injection of contrast, prolonged duration of procedure, biliary stricture dilation, experience of endoscopist, biliary stricture dilation, and other anatomical anomalies. ${ }^{[1-3]}$ It has been indicated that perforations caused by therapeutic ERCP procedures are often diagnosed in the late period. ${ }^{[4,7,8]}$ Considering results of our current study, it is thought that most common risk factors are history of Billroth II operation, dilatation of biliary stricture due to malignant or benign causes, anatomical anomalies (such as duodenal diverticula), fragile papilla Vateri, old age, difficult cannulation, pre-cut sphincterotomy and long procedure duration. Highrisk and/or elderly patients should only undergo endoscopy performed by very experienced endoscopist with careful and meticulous attention to reduce the risk of perforation.

Delayed diagnosis and surgical intervention may result in significant morbidity and mortality due to sepsis and multiple organ failure. Further, if surgery is delayed too long, exploration of retroperitoneal space is extremely difficult. Inflammation may be so severe that separation of normal anatomy is difficult or even impossible; perforation site often cannot be found in these patients.

There is much debate surrounding treatment of ERCP-related perforations, and treatment algorithm for ERCP-related perforations changes based on factors such as patient age and clinical status, comorbidities, time of certain diagnosis, size and location of perforation, time of surgery, and radiological findings. One of the most difficult issues for clinicians is early detection of patients who will require surgery. This decision requires multidisciplinary approach by gastroenterologist, surgeon, and anesthesiologist. Majority of authors have reported that radiological results, amount of retroperitoneal air, and/or pneumomediastinum are not correlated with clinical course; these data represent the amount of air used during ERCP and do not provide indication for surgery. ${ }^{[9-11]}$

Recently, it has been reported that most retroperitoneal perforations could be treated with conservative medical therapy; some authors have concluded that guidewire perforations are generally benign and do not require surgery. ${ }^{[12-14]}$ Certain patients are likely to improve under conservative management, which includes hospitalization, intestinal rest, and administration of intravenous fluids and antibiotics to limit peritonitis and allow perforation to seal. However, patients should undergo careful observation with frequent and repeated abdominal exams for early diagnosis of peritonitis. If patient is clinically stable and abdominal symptoms do not indicate deterioration due to peritoneal signs, patient can be treated non-surgically. Zuckerman et al. reported that early diagnosis of periampullary perforation and aggressive medical treatment led to clinical improvement without operative intervention in $86 \%$ of patients. ${ }^{[15]}$ In the current study, 6 patients were treated medically; all of them had repeat CT scans, all of which revealed decreasing amounts of air. Their laboratory findings and clinical course gradually improved without the need for surgery or any additional treatment methods. Ultimately, our experience suggests that certain patients with periampullary perforations can recover with this conservative treatment in early phase and avoid surgery.

While some authors have proposed early operations for all ERCP-related peritoneal perforations, recent studies have demonstrated the possibility of endoscopic perforation closure with endoscopic methods and they are being used with increasing frequency. ${ }^{[1,16-18]}$ It has been reported that peritoneal perforations can be sutured under endoscope. ${ }^{[17,19]}$ Successful closure with endoscopy in conservatively managed patients can reduce the fasting period, duration of intravenous antibiotic administration, and hospital stay. Moreover, it can improve patient quality of life and reduce medical costs. In the present study, 5 patients were successfully treated with endoscopic methods, while endoscopic treatment was unsuccessful in 2 patients. One of these 2 patients had duodenal perforation, and was treated with endoscopic clips. In this patient, both diagnosis and treatment were made during ERCP procedure. However, this treatment failed, and patient developed peritonitis.

Some authors have advocated a selective management algorithm for ERCP-related perforations. . $^{[7,-12]} \mathrm{Wu}$ et al. concluded that periampullary perforations should be treated aggressively with broad spectrum antibiotics, fasting, and aggressive endoscopic bile diversion (biliary stent or nasobiliary tube) from site of perforation. ${ }^{[9]}$ The authors went on to say that surgery is required if retroperitoneal fluid is seen on abdominal CT or if clinical picture worsens in 24 hours. In addition, the authors recommended surgery for all type I perforations (duodenal perforations).

Kim et al. proposed a new classification based on the instrument that caused the perforation: type $I$ injuries are caused by endoscopic tip or insertion tube, type 2 injuries occur due to sphincterotomy knives or cannulation catheters, and type 3 injuries are caused by guidewires after cannulation of the ampulla. The authors suggested that type I injuries require immediate surgical management after ERCP or immediate endoscopic closure during ERCP. In addition, they stated that surgical treatment should be considered in type 2 injuries with dirty fluid collection in the intra- and retroperitoneal area on $\mathrm{CT}$; if there is no fluid collection, conservative treatment is possible. ${ }^{[17]}$ Husain et al. reported that $33 \%(7 / 21)$ of patients showed extraluminal retroperitoneal 
air following ERCP; they concluded that it was not clinically significant. ${ }^{[20]}$ Stapfer et al. suggested that retroperitoneal air alone requires no additional treatment or further work-up if abdominal examinations are normal and there is no evidence or suspicion of contrast extravasation. Three of the patients in the current study had retroperitoneal air after ERCP via radiological findings, but symptoms were mild. In addition, vital signs and laboratory values of these 3 patients were also normal, and there was no fluid collection in retroperitoneal or intra-abdominal cavity. We successfully treated these patients with conservative management. Although very useful and different algorithms for the treatment of ERCP-related perforations have been suggested by several authors, it is the opinion of the authors of the present study that treatment modality is best decided on case-by-case basis, and must be individualized.

Mutignani et al. reported that fibrin glue was used to treat ERCP-related perforation. ${ }^{[21]}$ Seibert et al. successfully used endoscopic clipping to treat duodenal perforation that occurred during an endoscopic US examination. ${ }^{[19]}$ Based on these data, we suggest that, if possible, immediate closure by endoscopic methods should be used for ERCP-related perforation, followed by conservative management. However, in these instances, patient should be closely observed by specialists. If patient does not improve and rapidly deteriorates developing signs of intraabdominal sepsis within the first 48 hours despite conservative treatment, surgery should be considered immediately. Perforations detected in late period should be treated with conservative medical management in addition to surgical draining of fluid exudation or by percutaneous puncturing drainage; this can prevent or treat infection. ${ }^{[22,23]}$

As indicated, various treatment modalities were used in the current study, ranging from conservative techniques to surgical methods. Morever, patients underwent several different surgical procedures, including primary closure, T-tube choledochostomy, duodenal diverticulization, and Whipple operation. Authors believe that characteristics of each individual patient should determine most appropriate treatment modality and/or surgical method.

Mortality rate of ERCP-related perforations varies between $4.2 \%$ and $37 \%$, and delay in treatment of more than 24 hours after perforation can result in a doubling of mortality. ${ }^{[24-26]}$ In the current study, 4 of the patients who were diagnosed in the late period $(42,72,72$, and 88 hours) died due to uncontrollable sepsis; I patient had rheumatoid arthritis for 25 years and had been prescribed steroid drugs. Another of these patients was 85 years old and was diagnosed 42 hours after ERCP procedure; she had multiple comorbidities (CRF, hypertension, atherosclerotic heart disease, ejection fraction [EF] 65\%, type 2 DM and chronic anemia). The other deceased patient with type 3 perforation had peritonitis; he died just prior to surgery due to sepsis and other comorbidities during induction of anesthetic agents. In present study, mortality rate was $34.4 \%$ (10/29 patients). Although other results were similar to those in the literature, mortality ratio is comparatively higher. It is suggested that primary main causes for higher mortality in our study were delayed diagnosis, old age, high ASA score and perforation type.

In conclusion, ERCP-related perforation is an uncommon complication, but one that can cause extremely serious conditions. Early diagnosis and prompt management are important to decrease morbidity and mortality. Patients with ERCP-related perforations should be closely monitored in an intensive care unit (ICU) by gastroenterologist, anesthesiologist, and surgeon; this team should decide whether to proceed with surgery. The most appropriate treatment course should be decided on case-by-case basis. Although immediate surgical closure has been standard treatment for ERCPrelated perforation of duodenal wall, currently, endoscopic interventions using clips, endoloops, glue injection, and newly developed devices can be used in selected patients. It is believed that endoscopic treatment may develop further and that there will be several alternative methods to surgery in the near future.

\section{Conflict of interest: None declared.}

\section{REFERENCES}

1. Loperfido S, Angelini G, Benedetti G, Chilovi F, Costan F, De Berardinis F, et al. Major early complications from diagnostic and therapeutic ERCP: a prospective multicenter study. Gastrointest Endosc 1998;48:1-10.

2. Masci E, Toti G, Mariani A, Curioni S, Lomazzi A, Dinelli M, et al. Complications of diagnostic and therapeutic ERCP: a prospective multicenter study. Am J Gastroenterol 2001;96:417-23. Crossref

3. Enns R, Eloubeidi MA, Mergener K, Jowell PS, Branch MS, Pappas TM, et al. ERCP-related perforations: risk factors and management. Endoscopy 2002;34:293-8. Crossref

4. Stapfer M, Selby RR, Stain SC, Katkhouda N, Parekh D, Jabbour N, et al. Management of duodenal perforation after endoscopic retrograde cholangiopancreatography and sphincterotomy. Ann Surg 2000;232:191-8.

5. Howard TJ, Tan T, Lehman GA, Sherman S, Madura JA, Fogel E, et al. Classification and management of perforations complicating endoscopic sphincterotomy. Surgery 1999;126:658-65. Crossref

6. Williams EJ, Taylor S, Fairclough P, Hamlyn A, Logan RF, Martin D, et al. Risk factors for complication following ERCP; results of a large-scale, prospective multicenter study. Endoscopy 2007;39:793-801. Crossref

7. Fatima J, Baron TH, Topazian MD, Houghton SG, Iqbal CW, Ott BJ, et al. Pancreaticobiliary and duodenal perforations after periampullary endoscopic procedures: diagnosis and management. Arch Surg 2007;142:448-55. Crossref

8. Lee TH, Han JH, Park SH. Endoscopic treatments of endoscopic retrograde cholangiopancreatography-related duodenal perforations. Clin Endosc 2013;46:522-8. Crossref

9. Wu HM, Dixon E, May GR, Sutherland FR. Management of perforation after endoscopic retrograde cholangiopancreatography (ERCP): a population-based review. HPB (Oxford) 2006;8:393-9. Crossref

10. Lai CH, Lau WY. Management of endoscopic retrograde cholangiopancreatography-related perforation. Surgeon $2008 ; 6: 45-8$. Crossref 
11. Li G, Chen Y, Zhou X, Lv N. Early management experience of perforation after ERCP. Gastroenterol Res Pract 2012;2012:657418. Crossref

12. Alexiou K, Sakellaridis T, Sikalias N, Karanikas I, Economou N, Antsaklis G. Subcutaneous emphysema, pneumomediastinum and pneumoperitoneum after unsuccessful ERCP: a case report. Cases J 2009;2:120.

13. Fujii L, Lau A, Fleischer DE, Harrison ME. Successful Nonsurgical Treatment of Pneumomediastinum, Pneumothorax, Pneumoperitoneum, Pneumoretroperitoneum, and Subcutaneous Emphysema following ERCP. Gastroenterol Res Pract 2010;2010:289135. Crossref

14. Lee TH, Bang BW, Jeong JI, Kim HG, Jeong S, Park SM, et al. Primary endoscopic approximation suture under cap-assisted endoscopy of an ERCP-induced duodenal perforation. World J Gastroenterol 2010;16:2305-10. Crossref

15. Standards of Practice Committee, Zuckerman MJ, Shen B, Harrison ME 3rd, Baron TH, Adler DG, Davila RE, et al. Informed consent for GI endoscopy. Gastrointest Endosc 2007;66:213-8. Crossref

16. Nakagawa Y, Nagai T, Soma W, Okawara H, Nakashima H, Tasaki $\mathrm{T}$, et al. Endoscopic closure of a large ERCP-related lateral duodenal perforation by using endoloops and endoclips. Gastrointest Endosc 2010;72:216-7. Crossref

17. Kim BS, Kim IG, Ryu BY, Kim JH, Yoo KS, Baik GH, et al. Management of endoscopic retrograde cholangiopancreatography-related perforations. J Korean Surg Soc 2011;81:195-204. Crossref

18. Park WY, Cho KB, Kim ES, Park KS. A case of ampullary perforation treated with a temporally covered metal stent. Clin Endosc 2012;45:177-80.
19. Seibert DG. Seibert DG. Use of an endoscopic clipping device to repair a duodenal perforation. Endoscopy 2003;35:189. Crossref

20. Husain S, Garmager K, McPhee MS, Jacob KM, Fisher JK, Helzberg $\mathrm{JH}$. The significance of retroperitoneal air following endoscopic sphincterotomy. Gastrointest Endosc1995;41:400. Crossref

21. Mutignani M, Iacopini F, Dokas S, Larghi A, Familiari P, Tringali A, et al. Successful endoscopic closure of a lateral duodenal perforation at ERCP with fibrin glue. Gastrointest Endosc 2006;63:725-7. Crossref

22. Krishna RP, Singh RK, Behari A, Kumar A, Saxena R, Kapoor VK. Post-endoscopic retrograde cholangiopancreatography perforation managed by surgery or percutaneous drainage. Surg Today 2011;41:660-6.

23. Morgan KA, Fontenot BB, Ruddy JM, Mickey S, Adams DB. Endoscopic retrograde cholangiopancreatography gut perforations: when to wait! When to operate! Am Surg 2009;75:477-84.

24. Ercan M, Bostanci EB, Dalgic T, Karaman K, Ozogul YB, Ozer I, et al. Surgical outcome of patients with perforation after endoscopic retrograde cholangiopancreatography. J Laparoendosc Adv Surg Tech A 2012;22:371-7. Crossref

25. Alfieri S, Rosa F, Cina C, Tortorelli AP, Tringali A, Perri V, et al. Management of duodeno-pancreato-biliary perforations after ERCP: outcomes from an Italian tertiary referral center. Surg Endosc 2013;27:2005-12.

26. Miller R, Zbar A, Klein Y, Buyeviz V, Melzer E, Mosenkis BN, et al. Perforations following endoscopic retrograde cholangiopancreatography: a single institution experience and surgical recommendations. Am J Surg 2013;206:180-6. Crossref

\section{ORIJINAL ÇALIŞMA - ÖZET}

\section{Endoskopik retrograd kolanjiopankreatikografiye bağlı perforasyonların tedavisi \\ Dr. Cengiz Tavusbay, ${ }^{1}$ Dr. Emrah Alper, ${ }^{2}$ Dr. Melek Gökova, ${ }^{1}$ Dr. Erdinç Kamer, ${ }^{1}$ Dr. Haldun Kar, ${ }^{1}$ Dr. Kemal Atahan, Dr. Oğuzhan Özşay, ${ }^{1}$ Dr. Özlem Gür, ${ }^{1}$ Dr. Necat Cin, ${ }^{1}$ Dr. Emir Çapkınoğlu, ${ }^{1}$ Dr. Evren Durak ${ }^{1}$}

${ }^{1}$ İzmir Katip Çelebi Üniversitesi Tıp Fakültesi, Atatürk Eğitim ve Araştırma Hastanesi, Genel Cerrahi Kliniği, İzmir
${ }^{2}$ Izmir Katip Çelebi Üniversitesi Tıp Fakültesi, Atatürk Eğitim ve Araştırma Hastanesi, Gastroenterolojii Kliniği, İzmi

AMAÇ: Endoskopik retrograd kolanjiopankreatikografiye (ERKP) bağlı perforasyonlar az görülmelerine karşılık yüksek morbidite ve mortalite oranlarına sahiptir. Bu çalışmada ERKP'ye bağı perforasyonların tedavisi ve sonuçlarımıza ait tecrübelerimizi değerlendirmeyi ve ilgili literatürün gözden geçirilmesini amaçladık.

GEREÇ VE YÖNTEM: Ocak 2008 ve Ocak 2015 yılları arasında İzmir Katip Çelebi Üniversitesi, Atatürk Eğitim ve Araştırma Hastanesi Endoskopi Ünitesi'nde toplam 9383 ERKP işlemi yapıldı. Bu hastaların 29'unda (\%0.33), ERKP'ye bağı perforasyon tespit edildi ve bu hastalara ait veriler geriye dönük olarak değerlendirildi.

BULGULAR: Yirmi dokuz hastanın I 8'i kadın, I I'i erkek hasta olup, ortalama yaş 70.5 (33-99 yaşlar arası) idi. Stapfer sınıflandırmasına göre 5 hastada tip I, 14 hastada tip 2, 7 hastada tip 3 ve 3 hastada da tip 4 perforasyon saptandı. Toplam olarak, I5 hastaya cerrahi tedavi uygulandı; bunlardan 9'u (\%60) sorunsuz olarak taburcu edilirken, 6 (\%40) hasta ameliyat sonrası komplikasyonlardan dolayı öldü. Yirmi dokuz hastanın 7'sinde (\%24. I) ise başlangıçta endoskopik tedavi uygulandı ve bu hastalardan beşi sorunsuz olarak taburcu edildi. Ancak endoskopik tedavi iki hastada başarısız oldu. Peritonit gelişen bu 2 hastadan ilki, cerrahi tedavi sonrası sorunsuz olarak taburcu edildi. Cerrahi tedaviyi kabul etmeyen diğer hasta ise sepsis nedeni ile öldü. Altı hasta konservatif tıbbi tedavi ile başarılı bir şekilde tedavi edildi. Peritonit sonrası gelişen sepsis nedeniyle hayatını kaybeden 2 hastadan ilkinde hasta ve yakınlarının cerrahi tedaviyi reddetmesi nedeniyle, diğer hastada ise, anestezinin indüksiyon evresinde ani gelişen kardiyopulmoner arrest sonucu cerrahi tedavi yapılamadı. Çalışmamızda ortalama hastanede kalma süresi I3.2 gün (2-57), ölen hasta sayısı ise dokuz (\%3।) idi. TARTIŞMA: Endoskopik retrograd kolanjiopankreatikografiye bağlı perforasyonlar nadir görülmesine karşılık yüksek mortalite oranları yol açabilmesi nedeni ile son derece önemli bir klinik durumdur. Erken tanı ve tedavi mortalite ve morbidite oranlarının azaltılmasında çok önemlidir. En uygun tedavi yöntemi, hastanın bireysel özellikleri ve klinik durumu göz önünde bulundurularak verilmelidir. Anahtar sözcükler: Endoskopik retrograd kolanjiopankreatikografi (ERKP); endoskopik tedavi; perforasyon. 